\title{
PENERAPAN RECIPROCAL TEACHING UNTUK MENINGKATKAN KEMAMPUAN PEMAHAMAN KONSEP MATEMATIS SISWA MAN 1 SUBANG
}

\author{
Muhammad Iqbal Harisuddin ${ }^{1}$, Muhammad Faizal ${ }^{2}$ \\ 1,2STKIP Subang \\ 1akyssa.2@gmail.com
}

\begin{abstract}
The aim of this research is to find out whether the increase in the ability to understand mathematical concepts of MAN 1 Subang students is higher using the Reciprocal Teaching model than to obtain ordinary learning. The research method uses quasi-experimental research designs with Pretest-posttest Control Group Design. The experimental group used reciprocal teaching learning models while the control group used normal learning. The study population was all students of MAN 1 Subang with a sample of class $X$ students as many as two classes selected Nonrandom sampling. The instruments used in this study were in the form of tests and non-tests. The ability to understand students' mathematical concepts is measured by test instruments in the form of questions in the form of descriptions. Student responses are known with non-test instruments in the form of a questionnaire. The results showed an increase in the ability to understand mathematical concepts of MAN 1 Subang students higher using reciprocal teaching learning models than to obtain regular learning. Student responses using the reciprocal teaching learning model provide positive responses.
\end{abstract}

Keywords: Reciprocal Teaching, Understanding Mathematical Concepts

\section{ABSTRAK}

Penelitian ini dilakukan bertujuan untuk mengetahui apakah peningkatan kemampuan pemahaman konsep matematis siswa MAN 1 Subang lebih tinggi menggunakan model Reciprocal Teaching daripada memperoleh pembelajaran biasa. Metode penelitian menggunakan kuasi eksperimen dengan desain penelitian Pretest-posttest Control Group Design. Kelompok eksperimen model pembelajaran reciprocal teaching sedangkan kelompok kontrol menggunakan pembelajaran biasa. Populasi penelitian ini adalah seluruh siswa MAN 1 Subang dengan sampel penelitian siswa kelas X sebanyak dua kelas yang dipilih Non-random sampling. Instrumen yang digunakan dalam penelitian ini yaitu berupa tes dan non tes. Kemampuan pemahaman konsep matematis siswa diukur dengan instrumen tes berupa soal-soal yang berbentuk uraian. Respon siswa diketahui dengan Instrumen non tes berupa angket. Hasil penelitian menunjukkan peningkatan kemampuan pemahaman konsep matematis siswa MAN 1 Subang lebih tinggi menggunakan model pembelajaran reciprocal teaching daripada memperoleh pembelajaran biasa. Respon siswa menggunakan model pembelajaran reciprocal teaching memberikan respon positif.

Kata kunci : Reciprocal Teaching, Pemahaman Konsep Matematis 


\section{A. Pendahuluan}

Permen No. 23 Tahun 2006 mengeluarkan Standar Kompetensi Lulusan (SKL) (Depdiknas, 2007). Adapun SKL untuk mata pelajaran matematika diantaranya adalah Memahami konsep matematika, menjelaskan keterkaitan antarkonsep dan mengaplikasikan konsep atau algoritma secara luwes, akurat, efisien, dan tepat dalam pemecahan masalah. Menurut Ruseffendi (2006:156) bahwa "terdapat banyak peserta didik yang setelah belajar matematika, tidak mampu memahami bahwa pada bagian yang paling sederhana sekalipun, banyak konsep yang dipahami secara keliru sehingga matematika dianggap sebagai ilmu yang sukar, ruwet dan sulit.

Pemahaman konsep bagian yang paling penting dalam pembelajaran matematika". Seperti yang dikemukakan oleh O'Connell (dalam Fajarwati 2010:2) yang menyatakan bahwa dengan pemahaman konsep, siswa akan lebih mudah dalam memecahkan permasalahan karena siswa akan mampu mengaitkan serta memecahkan permasalahan tersebut dengan berbekal konsep yang sudah dipahaminya. Berkaitan dengan permasalahan diatas, salah satu langkah yang dapat dilakukan oleh guru untuk meningkatkan kemampuan pemahaman konsep matematis siswa adalah memilih model pembelajaran yang tepat dan efektif agar siswa menjadi aktif, dimana siswa akan lebih mudah menemukan dan memahami konsepkonsep yang sulit dipahami serta dapat belajar mandiri. Dalam hal ini, mandiri tidak diartikan bahwa siswa harus selalu mengkonstruksi konsep secara individual, tetapi mereka dapat mendiskusikan materi tersebut dengan siswa lainnya. Dengan menemukan materi secara mandiri, pengertian siswa tentang suatu konsep merupakan pengertian yang benar-benar dipahami oleh siswa. Hampir tidak mungkin mengatur kelas atau menyukseskan semua bagian pengajaran tanpa sungguhsungguh peduli pada siswa dan pola belajar mereka. (Jacobsen, D., Eggen, P., \& Kauchak, D, 2009:40).

Reciprocal Teaching salah satu model pembelajaran yang dilaksanakan supaya tujuan pembelajaran tercapai dengan tepat melalui proses belajar mandiri dan 
Didaktik : Jurnal IImiah PGSD STKIP Subang, ISSN Cetak : 2477-5673 ISSN Online : 2614-722X Volume VI Nomor 01, Juni 2020

siswa mampu menyajikannya di depan kelas. Hal ini sesuai dengan pendapat Palincsar (Shoimin 2017:153) bahwa dalam reciprocal teaching digunakan empat strategi pemahaman mandiri yaitu; question generating (membuat pertanyaan); clarifying mengklarifikasi istilah-istilah yang sulit dipahami); predicting (memprediksi materi lanjutan); dan summarizing (merangkum atau menyimpulkan). Diharapkan dengan diterapkanya model pembelajaran Reciprocal Teaching dalam pembelajaran matematika terjadinya peningkatan kemampuan pemahaman konsep matematis siswa yang lebih baik daripada siswa yang memperoleh pembelajaran biasa. Selain itu, diharapkan siswa memberikan repons positif terhadap penggunaan model pembelajaran reciprocal teaching.

Menurut Sanjaya (Siswoyo, 2013) mengemukakan pemahaman konsep adalah kemampuan siswa yang berupa penguasaan sejumlah materi pelajaran, tetapi mampu mengungkapkan kembali dalam bentuk lain yang mudah dimengerti, memberikan interpretasi data dan mampu mengaplikasi konsep yang sesuai dengan struktur kognitif yang dimilikinya. Adapun indikator yang menunjukkan pemahaman konsep menurut Peraturan Dirjen Dikdasdem Nomor 506/C/Kep/PP/2004 (dalam Widiarti, 2014:18) antara lain sebagai berikut; Menyatakan ulang sebuah konsep; Mengklarifikasi objek-objek menurut sifat-sifat sesuai dengan konsepnya; Memberikan contoh dan non contoh dari suatu konsep; Menyajikan konsep dalam berbagai bentuk representasi matematis; Mengembangkan syarat perlu atau syarat cukup suatu konsep; Menggunakan, memanfaatkan, dan memilih prosedur atau operasi tertentu; Mengaplikasikan konsep atau algoritma pemecahan masalah..

Pada penelitian ini tahapan / alur model pembelajaran reciprocal teaching (pembelajaran terbalik) yang akan digunakan adalah questioning clarifying - predicting - summarizing diaplikasikan dalam pelajaran untuk meningkatkan

kemampuan pemahaman konsep matematis siswa. Menurut teori Vygotsky, Zone of Proximal Developmnet (ZPD) merupakan celah antara actual development dan potensial development. Untuk memaksimalkan perkembangan, siswa seharusnya 
Didaktik : Jurnal IImiah PGSD STKIP Subang, ISSN Cetak : 2477-5673 ISSN Online : 2614-722X Volume VI Nomor 01, Juni 2020

bekerja dengan teman yang lebih terampil yang dapat memimpin secara sistematis dalam memecahkan masalah yang lebih kompleks. (Setiono, 2009).

\section{B. Metode Penelitian}

Metode penelitian yang digunakan dalam penelitian ini adalah metode kuasi eksperimen atau untuk melihat hubungan sebab-akibat dengan menggunakan dua kelompok. Variabel bebasnya adalah pembelajaran matematika dengan model pembelajaran reciprocal teaching, variabel terikatnya adalah untuk meningkatkan kemampuan pemahaman konsep matematis siswa.

Desain penelitian adalah desain kelompok kontrol pretes-postes (Pretest-posttest Control Group Design). Kelompok pertama sebagai kelompok eksperimen yang memperoleh pembelajaran dengan menggunakan model reciprocal teaching dan kelompok kedua sebagai kelompok kontrol yang memperoleh pembelajaran dengan pembelajaran biasa. Dimana masing-masing kelompok mendapatkan tes, baik itu tes awal (pretest) maupun tes akhir (posttest). Penggunaan metode ini bertujuan untuk mengetahui sejauh mana peningkatan kemampuan pamahaman konsep matematis siswa dengan model reciprocal teaching. Populasi seluruh siswa kelas $X$ MAN 1 Subang Tahun Ajaran 20182019, dengan sampel penelitian sebanyak dua kelas yang dipilih tidak secara acak (Non-random sampling). Kelompok eksperimen yaitu kelas $X$ MIA 3 model pembelajarannya reciprocal teaching sedangkan kelompok kontrol yaitu kelas X MIA 4 menggunakan model pembelajaran biasa. Instrumen yang digunakan dalam penelitian ini yaitu berupa tes dan non tes. Kemampuan pemahaman konsep matematis siswa diukur dengan instrumen tes berupa soal-soal yang berbentuk uraian. Respon siswa diketahui dengan Instrumen non tes berupa angket. Instrumen yang digunakan dalam penelitian ini yaitu berupa tes dan non tes. Data Kuantitatif berupa kemampuan pemahaman konsep matematis siswa diukur dengan instrumen tes berupa soal-soal yang berbentuk uraian. Data Kualitatif berupa respon siswa diketahui dengan Instrumen non tes berupa angket. Data kuantitatif nilai kemampuan pemahaman konsep 
matematis siswa.

Adapun alat untuk mengolah data hasil penelitian ini menggunakan bantuan Software Minitab 18 for Windows menggunakan taraf signifikan $\alpha=0,05$. Pengujian data hasil tes awal dan tes akhir tersebut meliputi uji normalitas dengan uji Kolmogorov-Smirnov. Uji kesamaan dua rerata hasil tes awal dan tes akhir berupa uji Mann-Whitney dengan data kelas eksperimen dan kelas kontrol berdistribusi tidak normal. Analisis peningkatan kemampuan pemahaman konsep matematis (Gain) meliputi Statistik deskriftif data Gain, Uji normalitas indeks gain dilakukan dengan menggunakan uji uji Kolmogorov-Smirnov, N-Gain kelas eksperimen dan kelas kontrol berasal dari populasi yang tidak berdistribusi normal. Sehingga langkah pengujian selanjutnya adalah uji kesamaan dua rerata dengan menggunakan dilakukan uji non-parametik (uji MannWhitney).

Data kualitatif pada akhir penelitian, siswa pada kelas eksperimen diberikan angket untuk mengetahui respon siswa terhadap pembelajaran menggunakan model Reciprocal Teaching dan peningkatan kemampuan pemahaman konsep matematis siswa. Angket berupa pernyataan-pernyataan yang mempunyai pilihan jawaban sangat setuju (SS), Tidak Setuju (TS), Setuju (S), Sangat Tidak Setuju (STS). Untuk mengolah data yang diperoleh dari angket dilakukan dengan menggunakan skala Likert.

\section{Hasil Penelitian dan \\ Pembahasan}

Seperti pada tabel 1 hasil penelitian yang ditampilkan, analisis tes awal (pretest) menggunakan uji non-parametrik yaitu uji MannWhitney menunjukan terdapat perbedaan rerata peringkat kemampuan awal pemahaman konsep matematis siswa kelas eksperimen dengan kelas kontrol. Setelah pembelajaran menggunakan model pembelajaran Reciprocal Teaching untuk kelas eksperimen dan pembelajaran biasa untuk kelas kontrol selama empat kali pertemuan dengan materi sistem persamaan linear tiga variabel, maka siswa diberikan tes akhir (posttest). Hasil analisis data posttest menunjukan bahwa rata-rata nilai siswa kelas eksperimen lebih tinggi yaitu 12,114 sedangkan rata-rata kelas kontrol 10,914, rata-rata skor $N$-Gain kelas 
Didaktik : Jurnal IImiah PGSD STKIP Subang, ISSN Cetak : 2477-5673 ISSN Online : 2614-722X Volume VI Nomor 01, Juni 2020

eksperimen adalah 0,7723 artinya bahwa Kelas Eksperimen (KE) mempunyai peningkatan kemampuan pemahaman konsep matematika yang tergolong tinggi sedangkan rata-rata skor N-Gain Kelas Kontrol (KK) adalah 0,1546 artinya kelas kontrol mempunyai peningkatan kemampuan pemahaman konsep matematika yang tergolong sedang.

Tabel 1

Rekapitulasi Data Hasil Pretest, Postest dan N-Gain

\begin{tabular}{|c|c|c|c|c|c|c|}
\hline & $P r$ & est & & ttest & $N-$ & ain \\
\hline & $\mathrm{KE}$ & $\mathrm{KK}$ & $\mathrm{KE}$ & $\mathrm{KKI}$ & $\mathrm{KE}$ & $\overline{K K}$ \\
\hline $\mathrm{N}$ & 35 & 35 & 35 & 35 & 35 & 35 \\
\hline Min & 4,00 & 1,0 & 9,00 & 8,00 & 0,285 & 0,14 \\
\hline & 0 & 00 & 0 & 0 & 7 & 29 \\
\hline Maks & 9,00 & 8,0 & 14,0 & 13,0 & 1,000 & 0,87 \\
\hline & 0 & 00 & 00 & 00 & & 50 \\
\hline Mea & 5,82 & 4,8 & 12,1 & 10,9 & 0,772 & 0,15 \\
\hline$n$ & 9 & 86 & 14 & 14 & 3 & 46 \\
\hline Vari & 1,44 & 2,5 & 1,69 & 1,13 & 0,023 & 0,01 \\
\hline ans & 0 & 16 & 2 & 9 & 9 & 81 \\
\hline$S D$ & 1,20 & 1,5 & 1,30 & 1,06 & 0,065 & 0,13 \\
\hline & 0 & 86 & 1 & 7 & 52 & 45 \\
\hline $\begin{array}{l}P- \\
\text { Val } \\
\text { ue }\end{array}$ & 0,0 & & & & & \\
\hline
\end{tabular}

Siswa yang mendapatkan pembelajaran dengan menggunakan model Reciprocal Teaching ini mengalami peningkatan kemampuan pemahaman konsep yang lebih tinggi, grafik 1 menunujukan $\mathrm{N}$-Gain KE (Pembelajaran Model Reciprocal
Teaching) lebih tinggi daripada $\mathrm{N}$ Gain KK (Pembelajaran biasa).

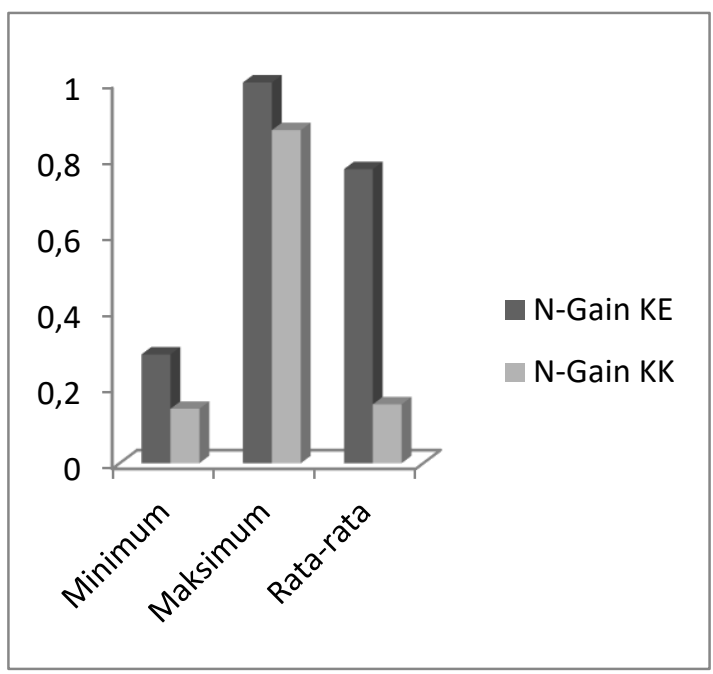

Grafik 1 Peningkatan Kemampuan

Pemahaman Konsep Matematis

Hal ini terjadi disebabkan model pembelajaran Reciprocal Teaching kepada siswa dapat memberikan kesempatan belajar mandiri dan mengembangkan kemampuani matematikanya. Dalam proses pembelajarannya pun siswa cenderung lebih aktif. Selain itu, dapat melatih siswa menjelaskan materi yang dipelajarinya kepada pihak lain, dengan demikian penerapan pembelajaran ini dapat dipakai siswa dalam mempresentasikan ide-idenya. Namun, pada awal pelaksanaan pembelajaran dikelas eksperimen terdapat beberapa hambatan yaitu, adanya perubahan cara mengajar guru sebagai hal yang tidak biasa dan memerlukan penyesuaian terhadap 
empat strategi yang terdapat pada model pembelajaran Reciprocal Teaching. Yaitu merangkum, menyusun pertanyaan, menjelaskan dan memprediksi.

Pada pertemuan pertama pembelajaran ini siswa masih bingung dengan tahapan pembelajaran yang diterapkan, sehingga ketika guru memperagakan peran siswa dalam kelompoknya untuk melakukan empat strategi dalam reciprocal teaching berjalan lama, dan siswa yang terpilih berperan sebagai guru pun tidak dapat berperan dengan baik. Pada pertemuan kedua, siswa mulai terbiasa dengan tahapan yang diterapkan dalam pembelajaran. Siswa yang terpilih berperan sebagai guru dapat melakukan tugasnya dengan baik. Tiap-tiap kelompok dapat menjalankan ke empat srategi yang terdapat pada model pembelajaran Reciprocal Teaching. Sehingga pelaksanaan pembelajaran pada pertemuan kedua dapat dikatakan baik. Pada pertemuan selanjutnya pun, pelaksanaan pembelajaran menggunakan model Reciprocal Teaching berjalan sesuai dengan yang direncanakan. Hal ini bisa dilakukan dengan Scaffolding yang merupakan suatu istilah pada proses yang digunakan orang dewasa untuk menuntun anak-anak melalui Zone of proximal developmentnya. Scaffolding adalah memberikan kepada seseorang anak sejumlah besar bantuan selama tahap - tahap awal pembelajaran dan kemudian mengurangi bantuan tersebut dan memberikan kesempatan kepada anak tersebut mengambil alih tanggung jawab yang semakin besar segera setelah ia mampu mengerjakan sendiri. (Setiono, 2009).

Pelaksanaan pembelajaran menggunakan model pembelajaran Reciprocal Teaching bukan berarti sukses secara keseluruhan dalam proses pembelajarannya, masih terdapat beberapa kekurangan yang ditemukan diantaranya masih ada siswa yang kurang memahami materi yang dibahas. Menurut Karim, 2012, "Pembelajaran Reciprocal Teaching diterapkan pada topik-topik yang esensial, sehingga siswa dapat menerapkan pengetahuan dan prosedur matematis yang telah mereka pelajari". Namun, siswa dapat mengikuti pembelajaran dengan baik dan serius dalam melaksanakan setiap tahap pembelajaran. Selain itu, pembelajaran matematika dengan model pembelajaran Reciprocal 
Didaktik : Jurnal IImiah PGSD STKIP Subang, ISSN Cetak : 2477-5673 ISSN Online : 2614-722X Volume VI Nomor 01, Juni 2020

Teaching ini membutuhkan waktu yang relatif lama, sehingga diperlukan persiapan rencana yang matang sebelum pembelajaran dimulai dan disesuaikan dengan alokasi waktu yang diberikan oleh pihak sekolah. Hal ini sejalan dengan hasil penelitian Karim (2012), "Pembelajaran Reciprocal Teaching memerlukan waktu yang lebih lama dari pembelajaran konvensional."

$$
\text { Menurut Jacobsen, D., Eggen, }
$$

P., \& Kauchak, D, 2009:217, Meskipun kemudahan, efisiensi dan penggunaannya sangat luas, ceramah sebagai metode pengajaran memiliki beberapa kekurangan penting; Tidak efektif untuk menarik dan mempertahankan perhatian siswa; Ceramah tidak memungkinkan guru untuk memeriksa persepsi dan pemahaman siswa yang tengah berkembang; Guru tidak dapat menentukan apakah siswa sudah menerjemahkan informasi dengan tepat atau tidak; Ceramah menempatkan siswa pada peran yang pasif.

Hasil analisis angket skala sikap, diperoleh bahwa respon siswa terhadap pembelajaran matematika dengan menggunakan model pembelajaran Reciprocal Teaching menunjukan respon yang positif. Siswa menjadi lebih memahami materi matematika dalam kegiatan pembelajaran. siswa belajar secara mandiri dan aktif dalam berdiskusi. Respon positif lainnya yang ditunjukkan siswa terhadap pembelajaran matematika menggunakan model pembelajaran Reciprocal Teaching yaitu siswa merasa lebih termotivasi dan bersemangat. Para guru yang mengatur kelas mereka secara efektif pada akhirnya dua hasil penting, yaitu : prestasi siswa meningkat dan motivasi siswa bertambah. (Jacobsen, D., Eggen, P., \& Kauchak, D, 2009:39). Aturan-aturan dan prosedur-prosedur tidak secara otomatis bekerja hanya karena aturan-aturan tersebut sudah ada dan telah disajikan pada siswa. Aturan dan prosedur ini seharusnya diperlukan sebagai konsep-konsep dan diajarkan secara eksplisit dengan contohcontoh sebagaimana anda akan mengajar konsep-konsep lainnya. (Downhower, 1991 dalam Jacobsen, D., Eggen, P., \& Kauchak, D, 2009:51).

\section{E. Kesimpulan}


Didaktik : Jurnal IImiah PGSD STKIP Subang, ISSN Cetak : 2477-5673 ISSN Online : 2614-722X

Volume VI Nomor 01, Juni 2020

Berdasarkan hasil penelitian, dapat ditarik kesimpulan bahwa mengenai kemampuan pemahaman konsep matematis siswa dengan menggunakan model pembelajaran Reciprocal Teaching (Pembelajaran Terbalik) yang dilakukan di MAN 1 SUBANG lebih baik daripada siswa yang memperoleh pembelajaran biasa. Selain itu, respon yang positif ditunjukkan siswa terhadap pembelajaran matematika dengan menggunakan model pembelajaran Reciprocal Teaching. Pembelajaran matematika dengan model pembelajaran Reciprocal Teaching (Pembelajaran Terbalik) ini membutuhkan waktu yang relatif lama, sehingga diperlukan persiapan rencana yang matang sebelum pembelajaran dimulai dan disesuaikan dengan alokasi waktu kurikulum.

Bagi calon peneliti yang hendak melakukan penelitian dengan model pembelajaran Reciprocal Teaching (Pembelajaran Terbalik), diharapkan untuk mencoba jenjang sekolah dan materi yang berbeda.

\section{DAFTAR PUSTAKA}

Depdiknas. (2007). Kajian Kebijakan Kurikulum Mata Pelajaran Matematika. Jakarta: Pusat
Kurikulum

Balitbang

Depdiknas

Fajarwati, M.S. (2010). Penerapan Model Reciprocal Teaching Sebagai Upaya Meningkatkan Pemahaman Konsep Matematika Siswa Kelas XI Akuntansi RSBI (Rintisan Sekolah Bertaraf Internasional) di SMK Negeri 1 Depok. Skripsi sarjana pada Fakultas Pendidkan MIPA Universitas Negeri Yogyakarta: tidak diterbitkan. [online].

Tersedia: http://eprints.uny.ac.id/2056/ 1/skripsi.pdf. $\quad[15$ januari 2018]

Fauzan, dkk. (2017). Kemampuan Pemahaman Matematis Siswa Melalui Model Pembelajaran Auditory intellectualy Repetition dan Problem Best Learning. STKIP Garut.

Jacobsen, D., Eggen, P., \& Kauchak, D. (2009). Methods For Teaching (Metode-Metode Pengajaran Meningkatkan Belajar Siswa TK- SMA) (Edisi ke-8). Yogyakarta : Pustaka Pelajar.

Joyce, B., Weil, M., \& Calhom, E., (2009). Models of Teaching (Model-model Pengajaran) (Edisi ke-8). Yogyakarta : Pustaka Pelajar.

Karim, Abdul. (2012). Meningkatkan Kemampuan Penalaran dan Berpikir Kritis Matematis Siswa SMP Melalui Pembelajaran Model Reciprocal Teaching. Tesis 
pada PPS UPI Bandung:

Tidak dipublikasikan.

Kesumawati, N. (2008). Prosiding Seminar Nasional

Matematika Dan Pendidikan Matematika. ISSN 978-97916353-1-8. [online]. Tersedia: http://eprints.uny.ac.id/id/epri nts/6928. [30 februari 2018]

Ruseffendi, E.T. (2006). Pengantar kepada Membantu Guru Mengembangkan

Kompetensinya dalam Pengajaran Matematika untuk Meningkatkan CBSA. Bandung: Tarsito (2005). Dasardasar Penelitian Pendidikan dab Bidang Non-Eksakta lainnya. Bandung: Tarsito

Sardiyanti, R. (2010). Penerapan \begin{tabular}{lr} 
Model & $\begin{array}{r}\text { Pembelajaran } \\
\text { Terbalik } \\
\text { Teachingocal } \\
\text { Untuk }\end{array}$ \\
Meningkatkan Aktivitas \\
Belajar Matematika Siswa. \\
Skripsi Jurusan Pendidikan \\
Matematika Fakultas IImu \\
Tarbiyah dan Keguruan UIN \\
Syarif Hidayatullah Jakarta: \\
tidak diterbitkan. [online]. \\
Tersedia: \\
http://repository.uinjkt.ac.id/ \\
\hline dspace/bitstream/1234567 \\
\hline 89/3353/1/RIA\%20SARDIY \\
\hline ANTI-FITK.pdf $[16$ januari \\
\hline 2018]
\end{tabular}

Shoimin, A. (2017). 68 Model Pembelajaran Inovatif dalam Kurikulum 2013. Yogyakarta: Ar-Ruzz Media

Siswoyo, D. (2013). Indikator Pemahaman Konsep
Matematika. [online] Tersedia:

http://dedi26.blogspot.com/ 2013/05/indikatorpemahaman-konsepmatematika.html. januari 2018]

Surono. (2017). Penerapan Model Reciprocal Teaching Untuk Meningkatkan Kemampuan Komunikasi Matematis Siswa (Studi pada Siswa Kelas VIII SMPN 19 Bandar Lampung T.P. 2016-2017). Skripsi sarjana pada Fakultas Keguruan Dan IImu Pendidikan Universitas Lampung: tidak diterbitkan. [online]. Tersedia: http://digilib.unila.ac.id/2827 6/3/SKRIPSI\%20TANPA\%2 OBAB\%20PEMBAHASAN.p df [20 januari 2018]

Widiarti, C. (2014). Pembelajaran Matematika Dengan Pendekatan Realistik Untuk Meningkatkan kemampuan Pemahaman Konsep Matematika Siswa. Skripsi sarjana Prodi Pendidikan Matematika STKIP Subang: Tidak diterbitkan 